九州大学学術情報リポジトリ

Kyushu University Institutional Repository

\title{
Analys is of the Tillage and Power Consumption Characteristics of a Crank-type Rotavator according to the Tillage Blade Shape
}

Kim, Dae-Chun

Department of Bio-Industrial Machinery Engineering, Chonbuk National University

Nam, Ju-Seok

Department of Biosystems and Biomaterials Science and Engineering, Seoul National University

Kim, Myoung-Ho

Department of Bio-Industrial Machinery Engineering, Chonbuk National University

Choe, Jung-Seob

Department of Precision Mechanical Engineering, Kyungpook National University

他

https://doi.org/10.5109/27363

出版情報: 九州大学大学院農学研究院紀要. 58 (2)，pp.319-328，2013-09. Faculty of Agriculture， Kyushu University

バージョン :

権利関係 : 


\title{
Analysis of the Tillage and Power Consumption Characteristics of a Crank-type Rotavator according to the Tillage Blade Shape
}

\author{
Dae-Chun KIM ${ }^{1}$, Ju-Seok NAM${ }^{2}$, Myoung-Ho KIM ${ }^{1}$, Jung-Seob CHOE ${ }^{3}$, \\ Eiji INOUE, Takashi OKAYASU and Dae-Cheol KIM ${ }^{1 *}$
}

\author{
Laboratory of Bioproduction Engineering, Division of Bioproduction Environmental Sciences, \\ Department of Agro-environmental Sciences, Faculty of Agriculture, \\ Kyushu University, Fukuoka 812-8581, Japan \\ (Received April 26, 2013 and accepted May 9, 2013)
}

\begin{abstract}
In this study, the effects of tillage blade shape on tillage and power consumption characteristics were investigated for a crank-type rotavator. Three types of tillage blades were applied, i.e. standard blade, endsloped blade and narrow blade for the purpose of the study. Tillage operations were carried out using each blade with the same prime mover tractor and rotavator platforms in two different soil and Power Take-Off (PTO) speed conditions. During the operations, PTO speed and torque, soil pulverizing ratio and inversion ratio, actual work speed, and rotavating width and depth were measured, and the required power of the PTO shaft, field capacity and flow of tilled soil were calculated to compare the characteristics according to the tillage blade shape. Experimental results show that the rotavating width, actual work speed, field capacity, flow of tilled soil and soil inversion ratio were independent of the blade shape, whereas the rotavating depth and soil pulverizing ratio were influenced by the blade shape according to the soil condition. In the most commonly used tractor gear conditions of L2 and L3, the PTO power of the end-sloped blade and narrow blade were almost the same as each other, and significantly lower than the standard blade in the paddy field, whereas there were no significant differences among blades in the dry field. It can be concluded that if an adequate blade shape suitable for specific soil conditions is applied to the crank-type rotavator, power efficiency and good tillage performance operation can be achieved at the same time. Further research is needed to determine the optimal shape of tillage blade with certain soil properties.
\end{abstract}

Key words: crank-type, required power, rotavator, tillage blade, tillage characteristics

\section{INTRODUCTION}

Tillage operations make a preferred environment for crop growth by improving the drainage and air permeability of a soil (Canarache, 1991), and rotavators are used for most of the operations (RDA, 2011). The most commonly used type of rotavator in Korea is a rotary-type rotavator which typically has 'C' or 'L' shaped tillage blades and 100 to $200 \mathrm{~mm}$ of rotavating depth. Because several tillage blades mounted on a flange continuously rotavate the subsurface soil, the tilling pitch is relatively short and the traction resistance greatly increased when the rotavating depth is increased. Therefore, the rotarytype rotavator is unsuited for the purpose of deep tillage. The other type of rotavator called a crank-type rotavator is commercialized in some European countries like Italy. It use several equally spaced spades as a tillage blade which represents a slider of a crank-slider mechanism and has a relatively deeper rotavating depth of 300 to $500 \mathrm{~mm}$. One tillage blade mounted on a flange results in a large tilling pitch and aggregate structure of the

\footnotetext{
1 Department of Bio-Industrial Machinery Engineering, Chonbuk National University, 567, Baekje-daero, Deokjin-gu, Jeonju-si, Jeollabuk-do, 561-756, Republic of Korea

2 Department of Biosystems and Biomaterials Science and Engineering, Seoul National University, Daehak-dong, Gwanak-gu, Seoul, 151-742, Republic of Korea

Department of Precision Mechanical Engineering, Kyungpook National University, Gajangdong, Sangju, Republic of Korea

* Corresponding Author (E-mail: dckim12@jbnu.ac.kr)
}

tilled soil (Cellicorea, 2008). The crank-type rotavator improves the crop yield by having a good influence on the air permeability and moisture contents of the soil (Varsa et al., 1997; Kim et al., 2001; Yoo et al., 2006).

Currently, both plowing and rotaty tillage operations are conducted by a tractor in Korea (MFAFF, 2006) and the working style is directed to the way of having only one time of tillage operation without separating into plowing or rotavating work for the saving of work hours and labor (Myung and Lee, 2000). The deep rotavating depth of the crank-type rotavator can represent this simultaneous working effect. However, few papers have addressed the crank-type rotavator in this country (NIAE, 2004; Nam et al., 2012) or internationally. Furthermore, the lack of actual field experience data makes it difficult to apply the crank-type rotavator to Korean farmland. Therefore, researches on several operational characteristics of the crank-type rotavator under specific soil conditions should be conducted for the development and implementation of the crank-type rotavator.

In this study, the effect of the tillage blade shape on tillage and power consumption characteristics of the crank-type rotavator was investigated by field operations in the Korean paddy and dry field. The results may be utilized as reference data for the selection of an optimum blade shape satisfying both high tillage performance and effective operation. 
Table 1. Specifications of the prime mover tractor used

\begin{tabular}{|c|c|c|}
\hline \multicolumn{2}{|c|}{ Item } & Specification \\
\hline \multicolumn{2}{|c|}{ Model/Company/Nation } & T623/Tongyang Moolsan/Korea \\
\hline \multicolumn{2}{|c|}{ Length/Width/Height (mm) } & $3,725 / 1,840 / 2,545$ \\
\hline \multicolumn{2}{|c|}{ Weight $(\mathrm{N})$} & 24,353 \\
\hline \multicolumn{2}{|c|}{ Engine rated power $(\mathrm{kW}) /$ speed $(\mathrm{rpm})$} & $48 / 2200$ \\
\hline \multicolumn{2}{|c|}{ No. of PTO gear (speed, rpm) } & $2(550 / 733)$ \\
\hline \multirow{2}{*}{ No. of T/M Gear } & Forward & 48 \\
\hline & Reverse & 48 \\
\hline \multirow{2}{*}{ Work Speed } & Minimum (km/h) & 0.89 \\
\hline & Maximum (km/h) & 28.33 \\
\hline
\end{tabular}

Table 2. Nominal work speed of the tractor

\begin{tabular}{cc}
\hline Gear & Nominal work speed $(\mathrm{km} / \mathrm{h})$ \\
\hline L1 & 0.89 \\
L2 & 1.41 \\
L3 & 2.17 \\
L4 & 2.70 \\
M1 & 2.85 \\
M2 & 4.51 \\
M3 & 6.94 \\
M4 & 8.64 \\
H1 & 9.35 \\
H2 & 14.81 \\
H3 & 22.77 \\
H4 & 28.33 \\
\hline
\end{tabular}

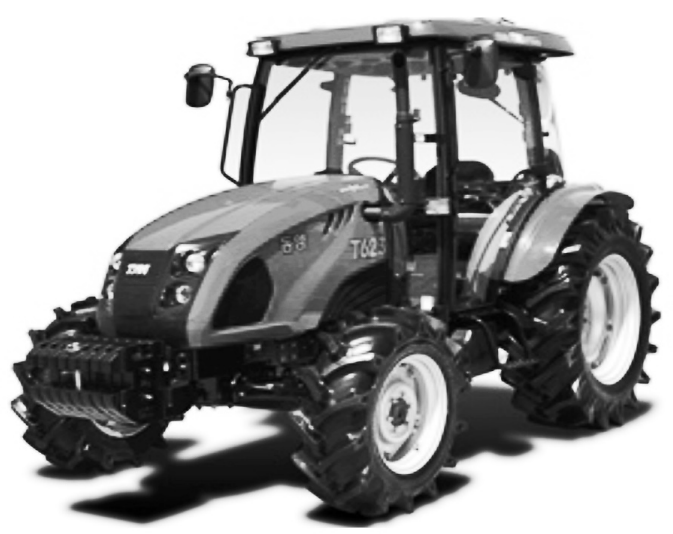

Fig. 1. A view of the tractor used in this study.

\section{MATERIALS AND METHODS}

\section{PRIME MOVER TRACTOR}

The prime mover tractor used for the operation of the rotavator was a T623 model of Tongyang Moolsan, Korea, and its specifications are shown in Table 1. The tractor is four-wheel drive, and the rated power and rated engine speed are $48 \mathrm{~kW}$ and $2200 \mathrm{rpm}$, respectively. The number of driving gears is 48 for both forward and backward directions, and the number of Power Take-Off
(PTO) gears is 2. The configuration and nominal work speed at each gear of the tractor are shown in Figure 1 and Table 2 , respectively.

\section{ROTAVATOR}

A crank-type rotavator of rated power $45 \mathrm{~kW}$ was used for the study. The configuration and specifications of the rotavator are shown in Figure 2 and Table 3, respectively.

In the rotavator, a total of 8 of shovel-shaped tillage blades are mounted on each flange of a crank-slider mechanism, and are classified as two types, i.e. the ones with length of bottom side of $110 \mathrm{~mm}$ and the other with length of bottom side of $140 \mathrm{~mm}$. A view of the tillage blade shape as well as the composition of the total rotavator structure is shown in Figure 3.

In the tillage operation of the rotavator, tillage blades cut the soil lump downward and the rotavating loads are the greatest at the moment of the first contact between

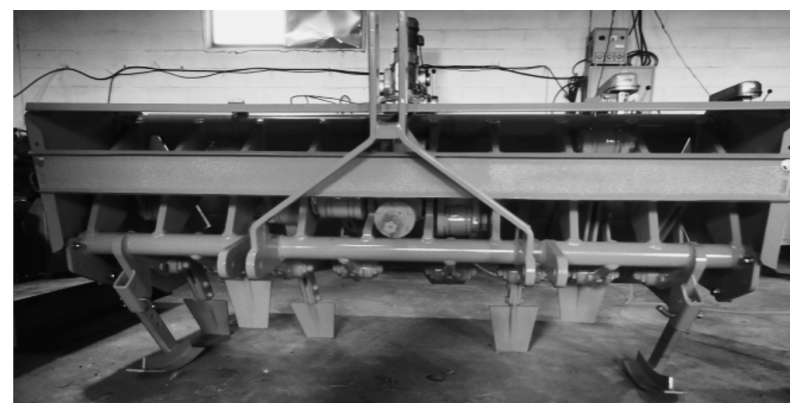

Fig. 2. A view of the crank-type rotavator.

Table 3. Specifications of the rotavator used

\begin{tabular}{cc}
\hline Item & Specification \\
\hline Model/Company/Nation & Prototype/Greenmax/Korea \\
Weight $(\mathrm{N})$ & 5,782 \\
Nominal rotavating width $(\mathrm{mm})$ & 1,800 \\
Rated power $(\mathrm{kW})$ & 45 \\
Nominal rotavating depth $(\mathrm{mm})$ & 300 \\
\hline
\end{tabular}




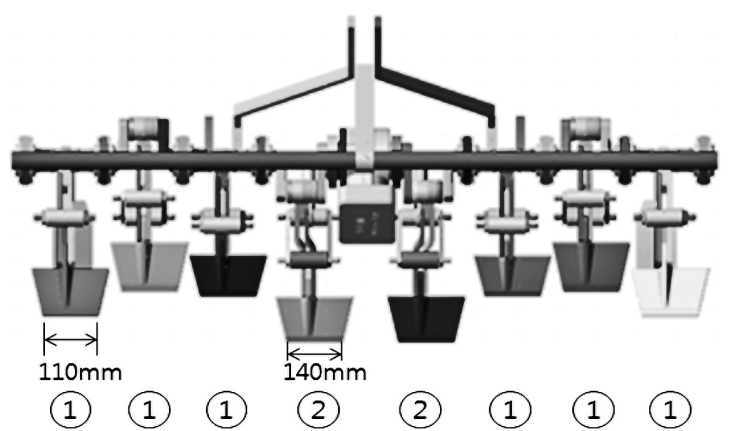

Fig. 3. The shape and composition of the tillage blades of the crank-type rotavator.

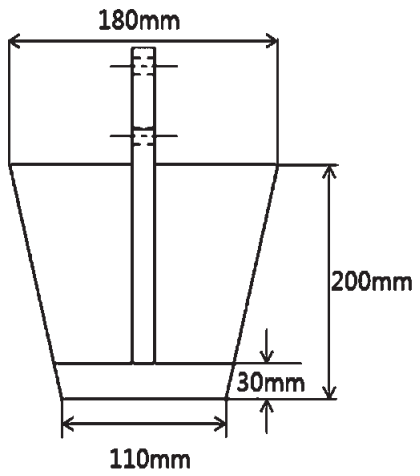

(a) Standard blade

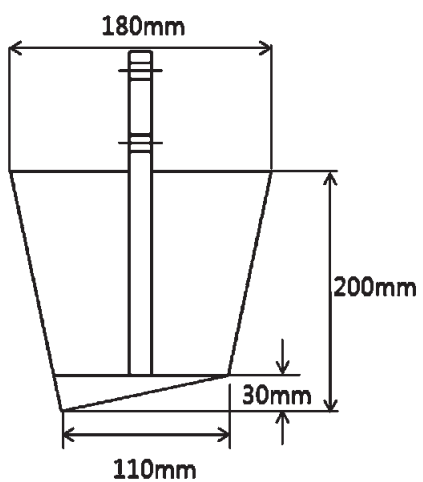

(b) End-sloped blade

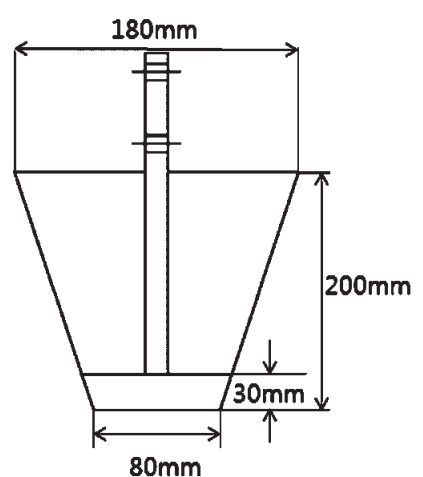

(c) Narrow blade

Fig. 4. Detailed shape of the tillage blades used for the study.

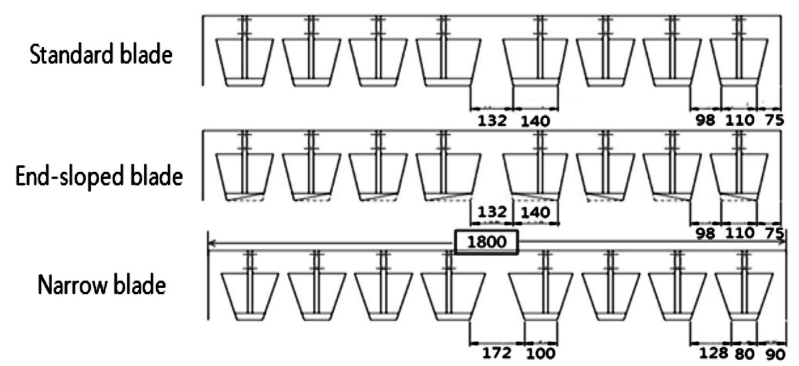

Fig. 5. The arrangement of tillage blades to form the rotavator structure.

the tillage blade and the soil when the rotating blade penetrates into the soil (Choi and Nahmgung, 2000). Because the tillage blade shape is the main factor to decide the magnitude of the rotavating loads (Seo et al., 2001), three different shapes of tillage blade were selected considering the power consumption and tillage related performances for the purpose this study. The three blades consist of the standard blade that is used on the rotavator as it is, an end-sloped blade that cuts the base line of standard blade along the diagonal line and a narrow blade that reduces the base line width of the standard blade from $110 \mathrm{~mm}$ to $80 \mathrm{~mm}$. The detailed shape of each tillage blade is shown in Figure 4.

The tillage blade arrangement for each shape is shown in Figure 5. The nominal rotavating width is $1800 \mathrm{~mm}$ for the three blade shapes. The three blades are vertically symmetric, and the spaces between the central two adjacent blades are $132 \mathrm{~mm}$ for the standard and end-sloped blades, and $172 \mathrm{~mm}$ for the narrow blade.

\section{EXPERIMENTAL SPOTS}

Two test sites were selected to see the influence of different soil conditions: A paddy field located in Sangwol-myeon, Nonsan-si, Chungcheongnam-do, Korea and a dry field located in Baekgu-myeon, Gimje-si, Jeollabuk-do, Korea. The paddy field ran to weeds while the dry field showed just a few weeds on it. A view of each experimental location is shown in Figure 6.

A cone penetrometer (SC900, Spectrum Technology, E Plainfield, USA) that complies with the related standard for the shape (ASAE S313.3, 2009) was used for the measurement of soil strength by a regulated test method (ASAE EP542, 2009). The measurement spots were randomly selected at different 4 locations of the test site, and the measurement depths were 5 points below the surface, i.e. from $50 \mathrm{~mm}$ to $250 \mathrm{~mm}$ at $50 \mathrm{~mm}$ intervals. The moisture content was measured at two different randomly selected locations of the test site using the oven method (ASAE S526.3, 2007). The soil texture was classified by the USDA method.

The cone index, moisture content and soil texture of the test site are shown in Table 4 . In the paddy field, the soil cone index was in the range of $140-2,317 \mathrm{kPa}$ and the moisture contents were $29.7 \%$ and $26.6 \%$ at each location. In the dry field, the soil cone index was in the range of $70-2,528 \mathrm{kPa}$ and the moisture contents were $15.5 \%$ and $14.2 \%$ at each location. The soil texture of the paddy 
Table 4. Soil properties of the experimental spots

\begin{tabular}{|c|c|c|c|c|c|c|c|c|}
\hline \multirow{2}{*}{ Site } & \multirow{2}{*}{ Soil texture } & \multirow{2}{*}{$\begin{array}{c}\text { Moisture content } \\
\text { [d.b.](\%) }\end{array}$} & \multicolumn{6}{|c|}{ Cone index by depth $(\mathrm{kPa})$} \\
\hline & & & Site & $5 \mathrm{~cm}$ & $10 \mathrm{~cm}$ & $15 \mathrm{~cm}$ & $20 \mathrm{~cm}$ & $25 \mathrm{~cm}$ \\
\hline \multirow{4}{*}{$\begin{array}{l}\text { Paddy } \\
\text { field }\end{array}$} & \multirow{4}{*}{$\begin{array}{l}\text { loamy } \\
\text { sand }\end{array}$} & \multirow{2}{*}{29.7} & 1 & 175 & 351 & 496 & 596 & 2,317 \\
\hline & & & 2 & 351 & 316 & 386 & 1,229 & 1,931 \\
\hline & & \multirow{2}{*}{26.6} & 3 & 245 & 210 & 316 & 316 & 491 \\
\hline & & & 4 & 140 & 210 & 245 & 351 & 2,317 \\
\hline \multirow{4}{*}{ Dry Field } & \multirow{4}{*}{$\begin{array}{l}\text { loamy } \\
\text { sand }\end{array}$} & \multirow{2}{*}{15.5} & 1 & 210 & 1,158 & 2,528 & 2,492 & 1,825 \\
\hline & & & 2 & 140 & 667 & 1,580 & 1,896 & 2,176 \\
\hline & & \multirow[b]{2}{*}{14.2} & 3 & 70 & 1,580 & 2,106 & 2,071 & 1,755 \\
\hline & & & 4 & 140 & 526 & 1,509 & 1,615 & 2,141 \\
\hline
\end{tabular}

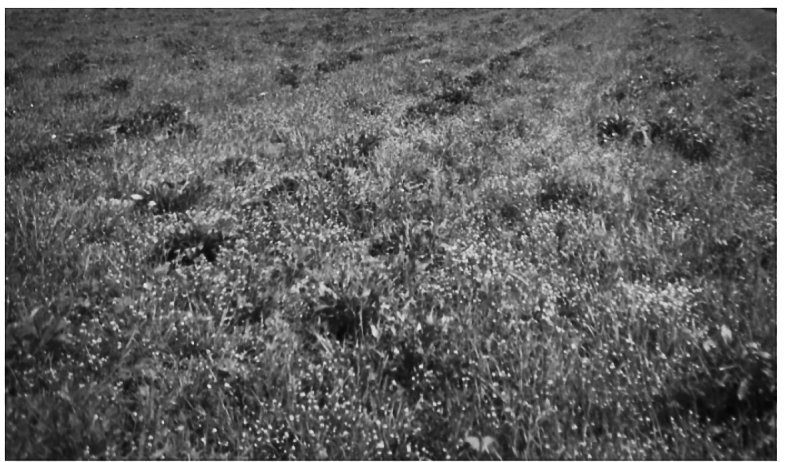

(a) Paddy field

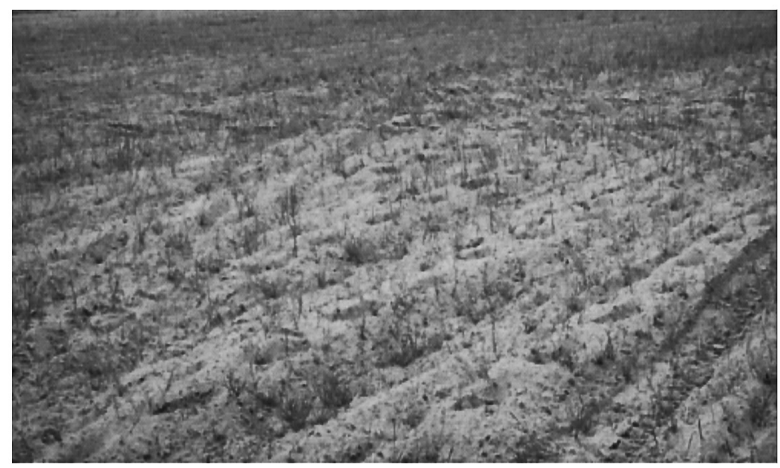

(b) Dry field

Fig. 6. A view of the experimental spots.

field was loamy sand which was comprised of $74 \%$ sand, $25.2 \%$ silt and $0.8 \%$ clay. The dry field was also loamy sand which was comprised of $70.4 \%$ sand, $28.7 \%$ silt and $0.9 \%$ clay.

\section{WORK CONDITIONS}

The tillage operations were conducted under specific gear conditions, as shown in Table 5, which include the most commonly used gear ranges in practice of L2 and L3 and additional gear ranges of L4 and M1 for comparison under several work speeds. The engine speed was fixed to a rated one all of the time. To also see the influence of the PTO speed, a different PTO speed was applied in the dry field. The PTO speed of the paddy field, however, was fixed to the lower one because of the hardness
Table 5. Gear of the rotavator operation

\begin{tabular}{cc}
\hline Site & Gear of Tractor/PTO \\
\hline Paddy field & L2, L3, L4, M1/1 \\
Dry field & L2, L3, L4, M1/1, 2 \\
\hline
\end{tabular}

of operation at the higher PTO speed. The actual rotavating distance was $15 \mathrm{~m}$ and was repeated two times for each operational condition. The sampling frequency of the data acquisition system was $600 \mathrm{~Hz}$ so that the noise signal from the engine speed, PTO speed and tillage blade's rotational speed would not disturb the reception of the original signals.

\section{MEASUREMENT AND ANALYSIS}

The speed and torque of the PTO shaft, rotavating depth and width, actual work speed of the tractor, pulverizing ratio and inversion ratio of the tilled soils were measured for the purpose of the study. Then the actual field capacity (the rotavating area per unit time), the PTO power and the flow of tilled soil (the volume of tilled soil per unit time) were calculated from the measured data.

The PTO shaft torque was measured by using a torque meter mounted on the PTO shaft (Figure 7 and Table 7), and the PTO speed was calculated by the speed of the transmission input shaft and reduction ratio of the transmission. A magnetic pick-up sensor mounted on the flange of the slip ring case was used for the transmission input shaft speed measurement (Figure 8). The PTO power was calculated by both the PTO shaft's torque and speed. The rotavating depth and width were measured with a tapeline at the center of the work distance, and the actual work speed was measured using a GPS installed in the tractor cap. The configuration and specifications of the GPS are shown in Figure 9 and Table 6, respectively.

The soil pulverizing ratio represents the capability of a rotavator to crush a lump of soil into fine particles. It was defined as the mass of tilled soil sample smaller than $20 \mathrm{~mm}$ in diameter over the total mass of the tilled soil sample. The larger the soil pulverizing ratio means the higher crushing the capacity of the rotavator. The soil sample was collected from a surface area of $600 \times 300 \mathrm{~mm}^{2}$ and to a depth of rotavating depth for each blade after 
tillage operation (NIAE, 2004). The soil inversion ratio represents the capability of the rotavator to turn the

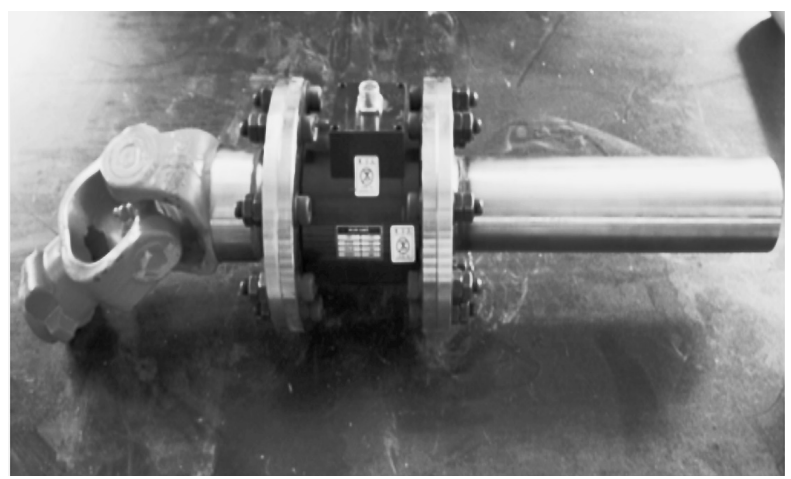

Fig. 7. A view of the PTO shaft torque meter.

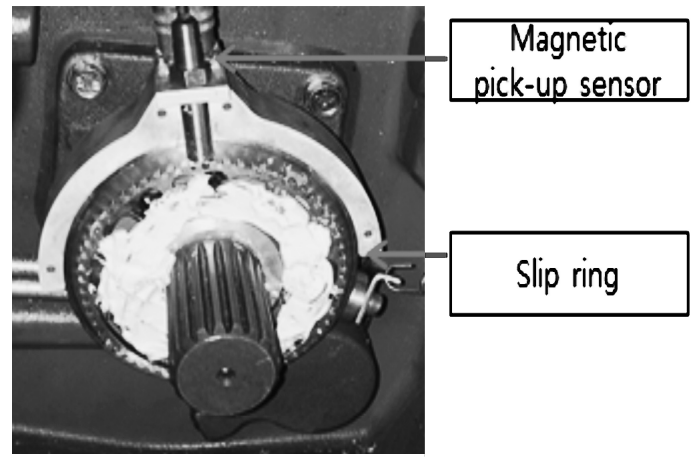

Fig. 8. Slip ring and magnetic pick-up sensor for the input transmission shaft speed measurement.

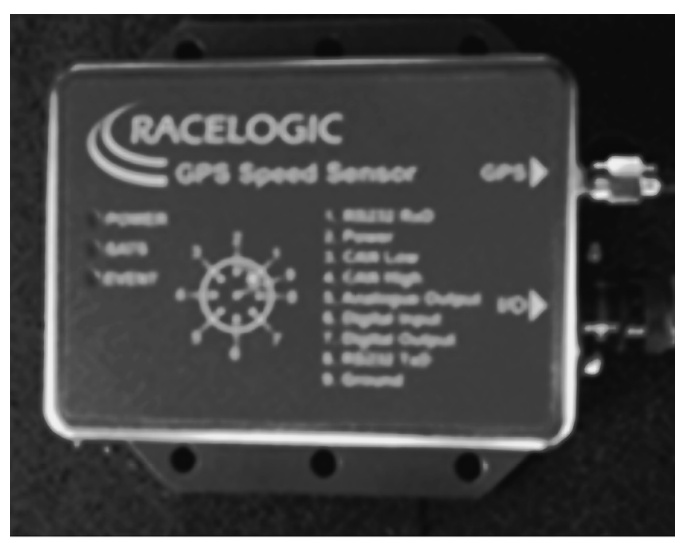

Fig. 9. Configuration of the GPS.

Table 6. Specifications of the GPS for actual work speed measurement

\begin{tabular}{cc}
\hline Item & Specification \\
\hline Model & TRE-100K \\
Manufacturer/Nation & DACELL/Korea \\
Rated output (mV/V) & 1.5 \\
Rated capacity (Nm) & 490.3 \\
Hysteresis (\%) & 0.3 \\
Temperature compensation $\left({ }^{\circ} \mathrm{C}\right)$ & $-10 \sim 60$ \\
\hline
\end{tabular}

inside soil over, and could be measured by comparing the distribution of lime on the soil surface before and after the tillage operation. The limed area for the soil inversion ratio was $1700 \times 1700 \mathrm{~mm}^{2}$ (NIAE, 2004)

Table 7. Specifications of the torque meter for PTO torque measurement

\begin{tabular}{cc}
\hline Item & Specification \\
\hline Model & VBSS05 \\
Manufacturer/Nation & RACELOGIC/United Kingdom \\
Output signal & Voltage \\
Maximum velocity $(\mathrm{km} / \mathrm{h})$ & 1610 \\
Minimum velocity $(\mathrm{km} / \mathrm{h})$ & 0.1 \\
Accuracy $(\%)$ & \pm 5
\end{tabular}

\section{RESULTS AND DISCUSSION}

\section{ACTUAL WORK SPEED OF TRACTOR, ROTAVATING DEPTH AND WIDTH, ACTUAL FIELD CAPACITY AND FLOW OF TILLED SOIL}

Table 8 shows some tillage performance results for the three blades.

In the paddy field, the average rotavating depth for the three blades was almost the same, i.e. $249 \mathrm{~mm}$, $254 \mathrm{~mm}$ and $254 \mathrm{~mm}$ for the standard blade, end-sloped blade and narrow blade, respectively. In contrast, in the dry field, some differences were observed among blades, i.e. the average rotavating depth of the above three blades were $251 \mathrm{~mm}, 236 \mathrm{~mm}$ and $225 \mathrm{~mm}$, respectively, for PTO gear 1, and $241 \mathrm{~mm}, 249 \mathrm{~mm}$ and $228 \mathrm{~mm}$, respectively, for PTO gear 2. It can be shown that the rotavating depth for the blade type is dependent on the soil conditions. The rotavating width was the same as the nominal value of $1800 \mathrm{~mm}$ all of the time, regardless of the soil condition and blade type.

The actual work speed according to the blade type didn't show clear tendencies, but was higher in the dry field than in the paddy field under the same blade type. This behavior may come from the larger skid effect of the hard dry field, as the blades of the rotavator push the tractor forward.

The actual field capacities among the three blades did not show significant differences. The errors were less than 10\% from each other under the same soil and gear conditions. Because the actual work speed and actual field capacity are independent of the blade shape, the flow of tilled soil for the three blades follows the tendency of the rotavating depth. That is, the flow of tilled soil according to the blade shape is dependent on the soil conditions. Like the actual work speed, the actual field capacity and the flow of tilled soil were higher in the dry field than in the paddy field under the same blade type.

\section{THE SOIL PULVERIZING RATIO AND INVERSION RATIO}

The crank-type rotavator rotavates the soil into an 
Table 8. Work performance of the crank-type rotavator measured at two experimental spots

\begin{tabular}{|c|c|c|c|c|c|c|c|}
\hline Site & Rotavator type & $\begin{array}{c}\text { Gear of } \\
\text { Tractor } \\
\text { /PTO }\end{array}$ & $\begin{array}{c}\text { Actual } \\
\text { work speed } \\
(\mathrm{km} / \mathrm{h})\end{array}$ & $\begin{array}{c}\text { Rotavating } \\
\text { depth } \\
(\mathrm{mm})\end{array}$ & $\begin{array}{c}\text { Rotavating } \\
\text { width } \\
(\mathrm{mm})\end{array}$ & $\begin{array}{c}\text { Actual field } \\
\text { capacity } \\
\left(\mathrm{m}^{2} / \mathrm{h}\right)\end{array}$ & $\begin{array}{c}\text { Flow of tilled } \\
\text { soil }\left(\mathrm{m}^{3} / \mathrm{h}\right)\end{array}$ \\
\hline \multirow{12}{*}{$\begin{array}{l}\text { Paddy } \\
\text { field }\end{array}$} & \multirow{4}{*}{ Standard blade } & $\mathrm{L} 2 / 1$ & 1.26 & 250 & 1,800 & 2268 & 567 \\
\hline & & $\mathrm{L} 3 / 1$ & 2.11 & 260 & 1,800 & 3798 & 987.48 \\
\hline & & $\mathrm{L} 4 / 1$ & 2.64 & 250 & 1,800 & 4752 & 1188 \\
\hline & & $\mathrm{M} 1 / 1$ & 2.79 & 235 & 1,800 & 5022 & 1180.17 \\
\hline & \multirow{4}{*}{ End-sloped blade } & $\mathrm{L} 2 / 1$ & 1.36 & 245 & 1,800 & 2448 & 599.76 \\
\hline & & $\mathrm{L} 3 / 1$ & 2.09 & 250 & 1,800 & 3762 & 940.50 \\
\hline & & $\mathrm{L} 4 / 1$ & 2.57 & 265 & 1,800 & 4626 & 1225.89 \\
\hline & & $\mathrm{M} 1 / 1$ & 2.71 & 255 & 1,800 & 4878 & 1243.89 \\
\hline & \multirow{4}{*}{ Narrow blade } & $\mathrm{L} 2 / 1$ & 1.25 & 250 & 1,800 & 2250 & 562.50 \\
\hline & & $\mathrm{L} 3 / 1$ & 1.99 & 260 & 1,800 & 3582 & 931.32 \\
\hline & & $\mathrm{L} 4 / 1$ & 2.49 & 250 & 1,800 & 4482 & 1120.50 \\
\hline & & & 2.67 & 255 & 1,800 & 4806 & 1225.53 \\
\hline \multirow{24}{*}{$\begin{array}{l}\text { Dry } \\
\text { field }\end{array}$} & \multirow{8}{*}{ Standard blade } & $\mathrm{L} 2 / 1$ & 1.62 & 275 & 1,800 & 3069 & 843.98 \\
\hline & & $\mathrm{L} 3 / 1$ & 2.42 & 235 & 1,800 & 4589 & 1066.71 \\
\hline & & $\mathrm{L} 4 / 1$ & 2.79 & 240 & 1,800 & 5292 & 1257.33 \\
\hline & & $\mathrm{M} 1 / 1$ & 3.01 & 255 & 1,800 & 5710 & 1460.06 \\
\hline & & $\mathrm{L} 2 / 2$ & 1.32 & 230 & 1,800 & 2508 & 571.09 \\
\hline & & $\mathrm{L} 3 / 2$ & 2.20 & 235 & 1,800 & 4171 & 969.43 \\
\hline & & $\mathrm{L} 4 / 2$ & 2.69 & 265 & 1,800 & 5102 & 1339.98 \\
\hline & & $\mathrm{M} 1 / 2$ & 2.82 & 235 & 1,800 & 5349 & 1257.23 \\
\hline & \multirow{8}{*}{ End-sloped blade } & $\mathrm{L} 2 / 1$ & 1.49 & 225 & 1,800 & 2822 & 628.14 \\
\hline & & $\mathrm{L} 3 / 1$ & 2.30 & 245 & 1,800 & 4361 & 1068.66 \\
\hline & & $\mathrm{L} 4 / 1$ & 2.79 & 235 & 1,800 & 5301 & 1245.64 \\
\hline & & $\mathrm{M} 1 / 1$ & 2.98 & 240 & 1,800 & 5653 & 1342.35 \\
\hline & & $\mathrm{L} 2 / 2$ & 1.39 & 255 & 1,800 & 2641 & 673.27 \\
\hline & & $\mathrm{L} 3 / 2$ & 2.23 & 255 & 1,800 & 4228 & 1078.73 \\
\hline & & $\mathrm{L} 4 / 2$ & 2.76 & 230 & 1,800 & 5235 & 1190.97 \\
\hline & & $\mathrm{M} 1 / 2$ & 2.96 & 255 & 1,800 & 5615 & 1431.46 \\
\hline & \multirow{8}{*}{ Narrow blade } & $\mathrm{L} 2 / 1$ & 1.45 & 240 & 1,800 & 2746 & 659.21 \\
\hline & & $\mathrm{L} 3 / 1$ & 2.24 & 235 & 1,800 & 4247 & 987.43 \\
\hline & & $\mathrm{L} 4 / 1$ & 2.79 & 220 & 1,800 & 5292 & 1164.23 \\
\hline & & $\mathrm{M} 1 / 1$ & 2.95 & 205 & 1,800 & 5596 & 1132.73 \\
\hline & & $\mathrm{L} 2 / 2$ & 1.43 & 240 & 1,800 & 2708 & 649.90 \\
\hline & & $\mathrm{L} 3 / 2$ & 2.25 & 235 & 1,800 & 4275 & 1004.44 \\
\hline & & $\mathrm{L} 4 / 2$ & 2.83 & 225 & 1,800 & 5368 & 1208.73 \\
\hline & & $\mathrm{M} 1 / 2$ & 2.96 & 210 & 1,800 & 5615 & 1195.05 \\
\hline
\end{tabular}

aggregate structure while the rotary-type rotavator tills the soil into a single grained structure (Figure 10).

Table 9 shows the soil pulverizing ratio and inversion ratio for the three blades. In the paddy field, the average soil pulverizing ratio in the gear range of L2 to M1 for standard blade, end-sloped blade and narrow blade were $82.16 \%, 80.14 \%$ and $67.93 \%$, respectively. In the dry field, the average soil pulverizing ratio of the above three blades were $92.59 \%, 91.88 \%$ and $89.17 \%$, respectively, at PTO gear 1, and 94.04\%, 90.64\% and 90\%, respectively, at PTO gear 2. It can be shown that the pul- verizing performances among blades did not show significant differences in the dry field, while the blade shape influenced the soil pulverizing performance in the paddy field. The pulverizing ratio for the blade type, therefore, is dependent on the soil conditions. In the case of the soil inversion ratio, regardless of the blade shape, soil condition and PTO speed, the values were 100\% at the L2 and L3 gears, 90\% at the L4 gear and 80\% at the M1 gear. As a result, the soil inversion performance was better at the lower work speed as in the study of Celik (2008), and it can be concluded that the soil inversion ratio is only 
Table 9. Soil pulverizing ratio and inversion ratio at each gear condition

\begin{tabular}{|c|c|c|c|c|}
\hline Site & Blade type & Gear of Tractor/PTO & Pulverizing ratio (\%) & Inversion ratio (\%) \\
\hline \multirow{12}{*}{$\begin{array}{l}\text { Paddy } \\
\text { field }\end{array}$} & \multirow{4}{*}{ Standard blade } & $\mathrm{L} 2 / 1$ & 79.40 & 100 \\
\hline & & $\mathrm{L} 3 / 1$ & 83.56 & 100 \\
\hline & & $\mathrm{L} 4 / 1$ & 83.29 & 90 \\
\hline & & $\mathrm{M} 1 / 1$ & 82.37 & 80 \\
\hline & \multirow{4}{*}{ End-sloped blade } & $\mathrm{L} 2 / 1$ & 79.46 & 100 \\
\hline & & $\mathrm{L} 3 / 1$ & 78.72 & 100 \\
\hline & & $\mathrm{L} 4 / 1$ & 84.04 & 90 \\
\hline & & $\mathrm{M} 1 / 1$ & 78.33 & 80 \\
\hline & \multirow{4}{*}{ Narrow blade } & $\mathrm{L} 2 / 1$ & 65.79 & 100 \\
\hline & & $\mathrm{L} 3 / 1$ & 69.88 & 100 \\
\hline & & $\mathrm{L} 4 / 1$ & 64.23 & 90 \\
\hline & & $\mathrm{M} 1 / 1$ & 71.81 & 80 \\
\hline \multirow{24}{*}{$\begin{array}{l}\text { Dry } \\
\text { field }\end{array}$} & \multirow{8}{*}{ Standard blade } & $\mathrm{L} 2 / 1$ & 88.04 & 100 \\
\hline & & $\mathrm{L} 3 / 1$ & 92.03 & 100 \\
\hline & & $\mathrm{L} 4 / 1$ & 95.14 & 90 \\
\hline & & M1/1 & 95.13 & 80 \\
\hline & & $\mathrm{L} 2 / 2$ & 95.62 & 100 \\
\hline & & $\mathrm{L} 3 / 2$ & 96.62 & 100 \\
\hline & & $\mathrm{L} 4 / 2$ & 93.03 & 90 \\
\hline & & $\mathrm{M} 1 / 2$ & 90.87 & 80 \\
\hline & \multirow{8}{*}{ End-sloped blade } & $\mathrm{L} 2 / 1$ & 85.54 & 100 \\
\hline & & $\mathrm{L} 3 / 1$ & 93.48 & 100 \\
\hline & & $\mathrm{L} 4 / 1$ & 93.33 & 90 \\
\hline & & $\mathrm{M} 1 / 1$ & 95.18 & 80 \\
\hline & & $\mathrm{L} 2 / 2$ & 89.98 & 100 \\
\hline & & $\mathrm{L} 3 / 2$ & 92.18 & 100 \\
\hline & & $\mathrm{L} 4 / 2$ & 91.00 & 90 \\
\hline & & $\mathrm{M} 1 / 2$ & 89.40 & 80 \\
\hline & \multirow{8}{*}{ Narrow blade } & $\mathrm{L} 2 / 1$ & 85.06 & 100 \\
\hline & & $\mathrm{L} 3 / 1$ & 88.10 & 100 \\
\hline & & $\mathrm{L} 4 / 1$ & 90.11 & 90 \\
\hline & & M1/1 & 93.39 & 80 \\
\hline & & $\mathrm{L} 2 / 2$ & 87.32 & 100 \\
\hline & & $\mathrm{L} 3 / 2$ & 90.33 & 100 \\
\hline & & $\mathrm{L} 4 / 2$ & 90.88 & 90 \\
\hline & & $\mathrm{M} 1 / 2$ & 91.46 & 80 \\
\hline
\end{tabular}

dependent on the work speed.

\section{PTO TORQUE}

The PTO torque during tillage operation for the three blades was measured under different soil and PTO speed conditions, and the results are shown in Figure 11.

In the paddy field, the average PTO torques for standard blade, end-sloped blade and narrow blade under the most commonly used gear conditions of L2 and L3 were $658.98 \mathrm{Nm}, 398.58 \mathrm{Nm}$ and $390.21 \mathrm{Nm}$, respectively. In the case of the dry field, the average PTO torques for the above three blades were $399.12 \mathrm{Nm}, 360.49 \mathrm{Nm}$ and $356.06 \mathrm{Nm}$, respectively, at PTO gear 1, and 519.32 Nm, 469.94 Nm and 526.06 Nm, respectively, at PTO gear 2.

The PTO torque of the standard blade was significantly higher than the other blades' torque in the paddy field. This difference, however, reduced in the dry field at PTO gear 1, and the narrow blade's torque exceeded the standard blade's torque in the dry field at PTO gear 2. In the dry field, the differences of PTO torque among the three blades were not significant because the errors were within 10\% each other. The PTO torque decreased as the 


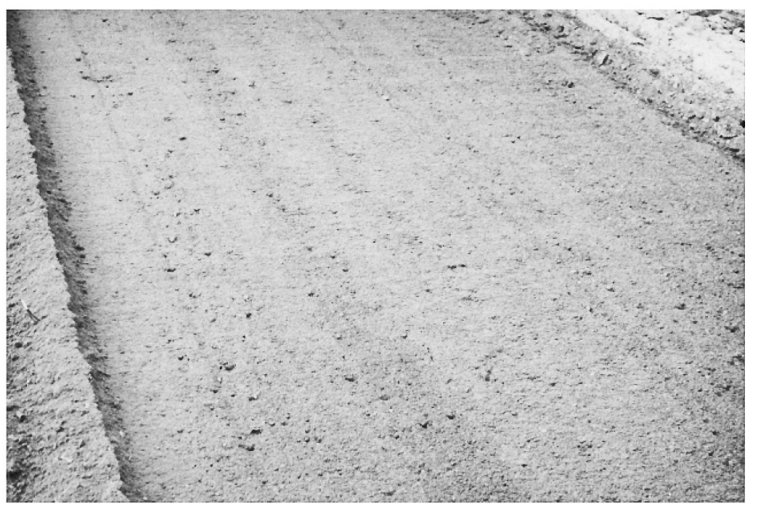

(a) Rotary-type

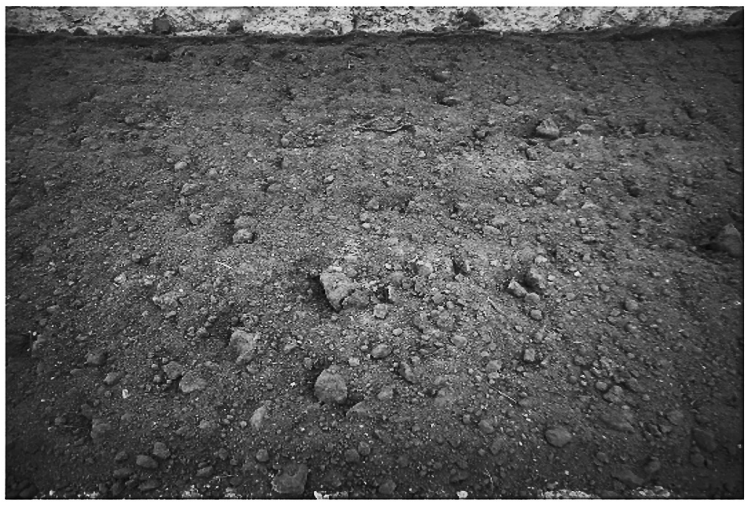

(b) Crank-type

Fig. 10. A view of the pulverized soil according to the rotavator type.

actual work speed increased at the PTO gear 1 which agrees with the trend of the rotary-type rotavator (Kim et al., 2000), but there were no clear tendencies related to the actual work speed at PTO gear 2 . The average PTO torque in the paddy field was higher than in the dry field under the same PTO and work speed conditions, and the gap was the greatest in the standard blade. From the point of view of the PTO speed, the average PTO torque was proportional to the PTO speed as shown in the results of the dry field.

\section{PTO POWER}

The required power of the PTO shaft during tillage operation for the three blades was measured under different soil and PTO speed conditions, and the results are shown in Figure 12.

In the paddy field, the average PTO power for the standard blade, end-sloped blade and narrow blade at the most commonly used gear conditions of L2 and L3 were $36.33 \mathrm{~kW}, 22.87 \mathrm{~kW}$ and $22.42 \mathrm{~kW}$, respectively. The power of the end-sloped blade and narrow blade were almost the same, and about 37\% lower compared with the power of the standard blade. The standard blade use about $76 \%$ of the tractor rated power while the endsloped and narrow blade used only about $47 \%$ of tractor rated power. From the point of view of tractor power consumption, therefore, the use of the end-sloped or

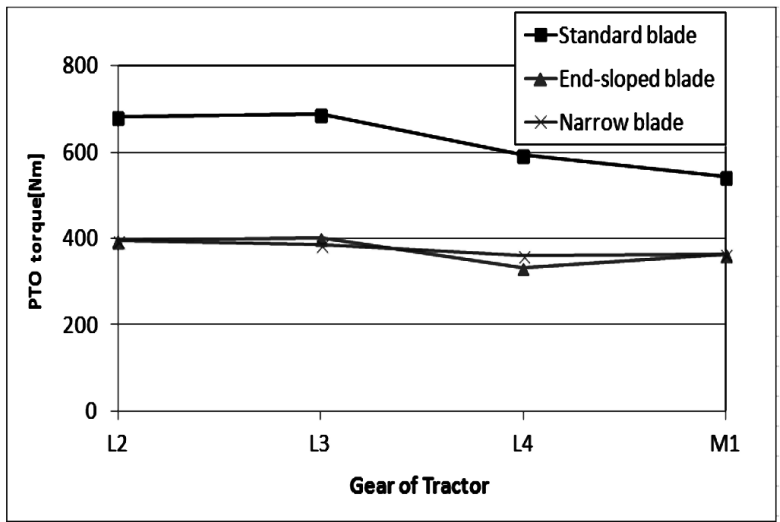

(a) Paddy field

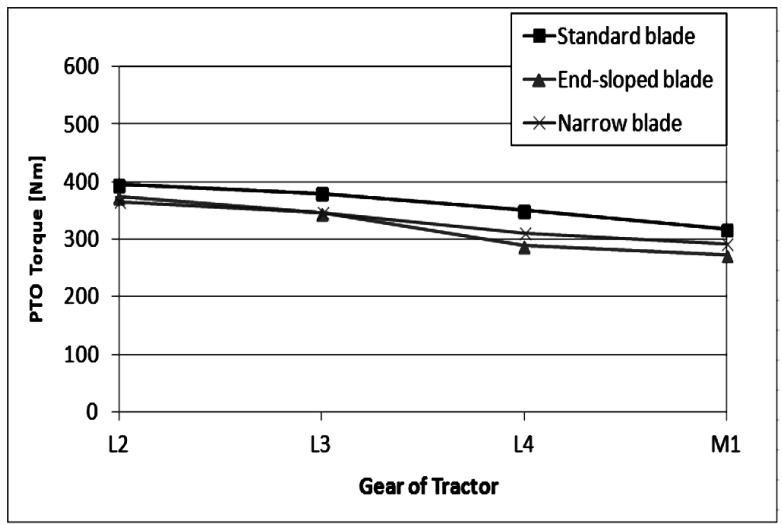

(b) Dry field: PTO 1

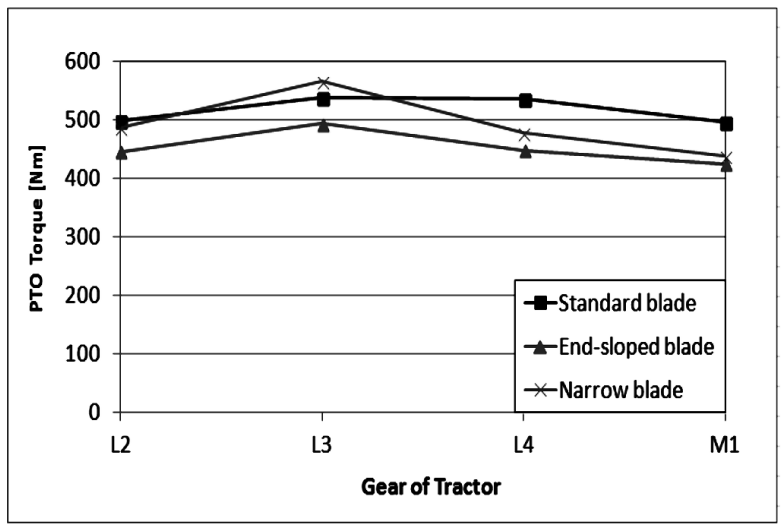

(c) Dry field: PTO 2

Fig. 11. The PTO torque plot according to the blade shape.

narrow blade can save about 29\% of the tractor power.

In the case of the dry field, the average PTO power for the above three blades were $22.38 \mathrm{~kW}, 20.88 \mathrm{~kW}$ and $20.43 \mathrm{~kW}$, respectively, at PTO gear 1 , and $39.09 \mathrm{~kW}$, $35.61 \mathrm{~kW}$ and $39.66 \mathrm{~kW}$, respectively, at PTO gear 2. The average PTO power the trend among three blades corresponded to the trend of the PTO torque, i.e. the value of the standard blade and narrow blade were the greatest at PTO gears 1 and 2, respectively, although the PTO power of all blades was within the margin of error. At PTO gear 1, the standard blade used about $47 \%$ of the 


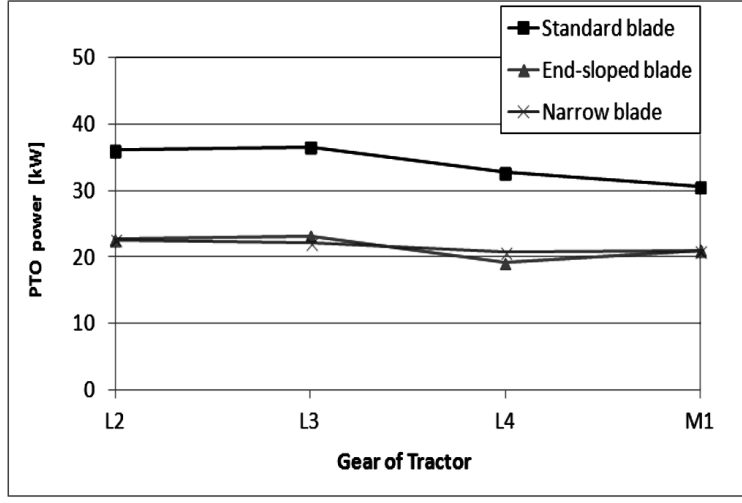

(a) Paddy field

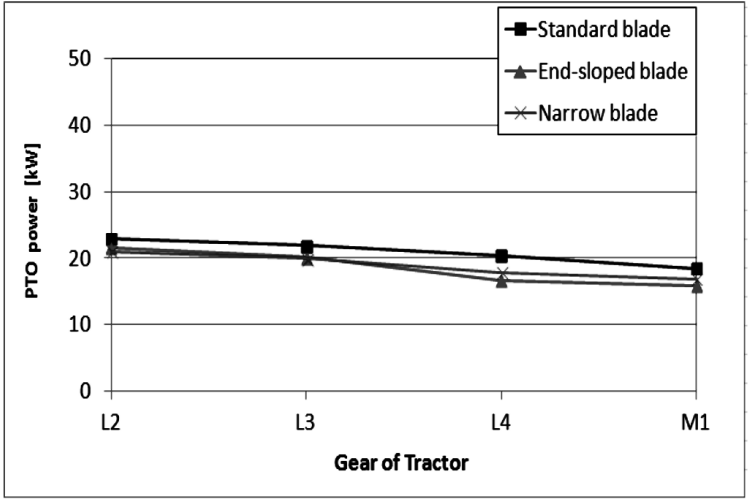

(b) Dry field: PTO 1

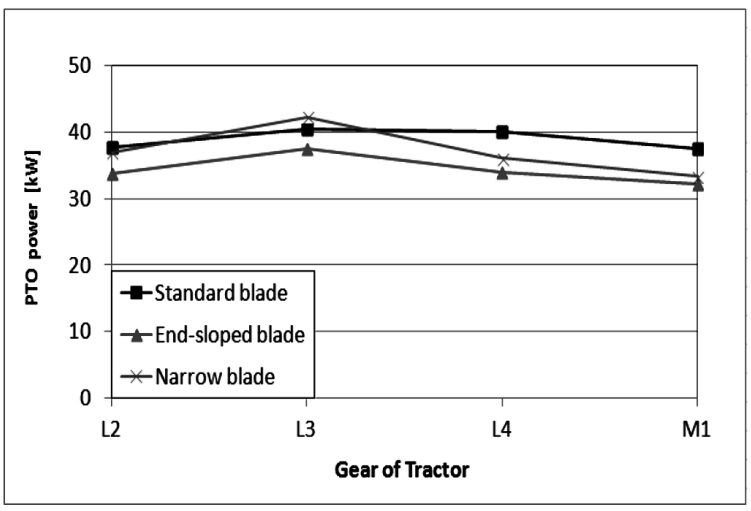

(c) Dry field: PTO 2

Fig. 12. The PTO power plot according to the blade shape.

tractor rated power while the end-sloped and narrow blade used about $43 \%$ of the tractor rated power. At PTO gear 2, the standard and narrow blade used about $82 \%$ of the tractor rated power while the end-sloped blade used about $74 \%$ of the tractor rated power. Therefore, in the dry field, it is more advantageous to use the endsloped and narrow blades for PTO gear 1 and the endsloped blade for PTO gear 2 to reduce tractor power consumption.

As shown in the results of the dry field, the average PTO power was proportional to the PTO speed, and this agrees with the study of Kim et al. (2011). Under the same PTO and work speed conditions, the power saving effect according to the use of different shape of blade was much more higher in the paddy field than in the dry field.

\section{SUMMARY AND CONCLUSIONS}

This study has been conducted to investigate the influence of the tillage blade shape on the tillage and power consumption characteristics of a crank-type rotavator. Three different shapes of tillage blades, i.e. the standard blade, end-sloped blade and narrow blade were designed and manufactured for the purpose of the study. The tillage operation using each blade was conducted under two different soil and PTO speed conditions as well as various actual work speed conditions, and several parameters such as the PTO speed and torque, rotavating depth and width, actual working speed, field capacity, flow of tilled soil, soil pulverizing ratio and inversion ratio were measured and analyzed.

The main findings of this study are as follows:

(1) The average rotavating depths among the three blades were almost the same in the paddy field while a slight difference was observed in the dry field. For the rotavating width, actual work speed, actual field capacity and the flow of tilled soil, most of the errors among the blades were within $10 \%$ of each other at the same soil and gear conditions, and as a result, it did not show clear tendency according to the blade shape.

(2) The pulverizing performances among blades did not show significant differences in the dry field. There were, however, some distinguishing characteristics in the paddy field, i.e. the standard blade and endsloped blade showed almost the same pulverizing ratio and this was higher than the narrow blade's value. The soil inversion performance was not influenced by the blade shape, but was only dependent on the work speed.

(3) Under the most commonly used gear conditions, the PTO torque of the standard blade was significantly higher than the other blades' torque in the paddy field. In the dry field, however, there were no significant differences in the PTO torque among the three blades. Therefore, the influence of the tillage blade shape on the PTO torque was dependent on the soil condition.

(4) In the paddy field and under the most commonly used gear condition, the use of end-sloped and narrow blades can reduce tractor power consumption by $29 \%$ compared to the case of using the standard blade. In the dry field and under the most commonly used gear condition, although the differences were not significant, it was shown that the endsloped blade and narrow blade can reduce tractor power consumption by $4 \%$ compared to the standard blade at PTO gear 1. Also, the end-sloped blade in the dry field can reduce tractor power consumption by $8 \%$ compared to the standard blade and narrow blade at PTO gear 2. Therefore, even though the effect is dependent on the soil condition, the use 
of the end-sloped blade is the most advantageous from the point of view of tractor power saving.

(5) To sum up aspects of both the tillage characteristics such as rotavating depth and width, actual work speed, actual field capacity, flow of tilled soil, soil pulverizing ratio and inversion ratio and power consumption characteristics, the use of the end-sloped blade in the paddy field can be the best solution because it has the same tillage performances as the standard blade while the power consumption of the tractor is significantly lower. However, in the dry field, the use of a different blade from the standard blade has little influence on the tillage and power consumption characteristics, and sometimes it may be a bad solution because of the manufacturing cost of a new blade.

(6) To develop the optimum shape of a tillage blade suitable for a certain operational condition, more studies are required for evaluation and a database needs to be made of the impact of various parameters such as blade shape and soil conditions.

\section{ACKNOWLEDGEMENT}

This paper was supported by research funds of Chonbuk National University in 2010.

\section{REFERENCES}

ASAE standards. 2007 Soil and water terminology. ASAE S526.3 SEP2007, American Society of Agricultural Engineering

ASAE standards, 2009 Procedures for using and reporting data obtained with the soil cone penetrometer. ASAE EP542 FEB1999, American Society of Agricultural Engineering

ASAE standards, 2009 Soil cone penetrometer. ASAE S313.3 FEB1999, American Society of Agricultural Engineering

Canarache, A. 1991 Factors and indices regarding excessive compactness of agricultural soils. Soil and Tillage Research, 19: $145-164$

Celik, A and S. Altikat. 2008 Geometrical analysis of the effects of rotary tiller blade path on the distribution of soil slice size.
Applied Engineering in Agriculture, 24(4): 409-413

Cellicorea. 2008 Application of crank-type rotavator. Available at: www.cellicorea.com

Choi, C. H and M. J. NahmGung. 2000 Load Measurement of Tractor on Field Performance. Proceedings of the KSAM 2000 summer conference, $\mathbf{2 5}(0)$ : 29-34

Kim, J. H., K. U. Kim and Y. G. Wu. 2000 Analysis of transmission load of agricultural tractors. Journal of Terramechanics, 37(3): 113-125

Kim, Y. J., S. O. Chung, C. H. Choi and D. H. Lee. 2011 Evaluation of tractor PTO severeness during rotary tillage operation. Journal of Biosystems Engineering, 36(3): 163-170

MFAFF. 2006 Development of Optimal Tillage System Based on Soil Physical Properties. Ministry for Food Agriculture Forestry and Fisheries, Gwacheon, Korea

Myung, B. S and H. D. Lee. 2009 Research on the actual condition of rotary tilling \& rotary power requirement in the central area. Journal of Korean Society of Industrial Application, 12(2): 79-83

Nam, J. S., D. C. Kim, M. H. Kim and D. C. Kim. 2012 Tillage characteristics estimation of crank-type and rotary-type rotavator by motion analysis of tillage blades. Journal of Biosystems Engineering, 37(5): 279-286

Nam, J. S., D. S. Kang, Y. S. Kang, K. U. Kim and D. C. Kim. 2012 Comparison of work perfprmance of crank-type and rotarytype rotavators in Korean farmland conditions. Journal of Biosystems Engineering, 37(3): 140-147

NIAE. 2004 Experimental and research report. National Institute of Agricultural Engineering, Suwon, Korea

RDA. 2011 A Study utilization of agricultural machinery and mechanization ratio. Rural Development Administration, Suwon, Korea

Seo, D. H., W. P. Park, C. S. Kim, C. H. Choo, S. H. Kim and K. D. Kim. 2001 Development of energy saving rotary blade for tractor - rotary power requirement for the second tillage at paddy field. Proceedings of the KSAM 2001 summer conference, $\mathbf{2 5}$ (1): 79-84

Yoo, C. H., J. H. Ryu, C. H. Yang, T. K. Kim, S. W. Kang, J. D. Kim and K. Y. Jung. 2006 Influence of diagnostic fertilization and subsoil breaking on soil physico-chemical properties in direct seeding of rice on flooded paddy surface. Journal of Korean Society of Soil Science and Fertilizer, 39(6): 334-338

Varsa, E. C., S. K. Chong, J. O. Aboaji, D. A. Farquhar and F. j. Olsen. 1997 Effect of deep tillage on soil physical characteristics and corn (Zea mays L.) root growth and production. Soil and Tillage Research, 43: 219-228 